\title{
Correlation of Cytogenetic, Molecular and Clinical Findings in Thalassemia Patients at a Tertiary Care Hospital
}

\author{
Nitu Nigam¹, Nishant Verma², Monica Agrawal ${ }^{3}$, Harish Gupta4, Prithvi Kumar Singh'5 Sujata Deo ${ }^{6}$, \\ Shailendra K. Saxena?
}

\begin{abstract}
${ }^{1}$ Department of Centre for Advance Research (Cytogenetics Lab), King George's Medical University, Lucknow, Uttar Pradesh, India. ${ }^{2}$ Department of Paediatrics, King George's Medical University, Lucknow, Uttar Pradesh, India. ${ }^{3}$ Department of Obstetrics and Gynaecology, King George's Medical University, Lucknow, Uttar Pradesh, India. ${ }^{4}$ Department of Medicine, King George's Medical University, Lucknow, Uttar Pradesh, India. ${ }^{5}$ Department of Centre for Advance Research (Cytogenetics Lab), King George's Medical University, Lucknow, Uttar Pradesh, India. ${ }^{6}$ Department of Obstetrics and Gynaecology, King George's Medical University, Lucknow, Uttar Pradesh, India. ${ }^{7}$ Department of Centre for Advance Research; King George's Medical University, Lucknow, Uttar Pradesh, India.
\end{abstract}

\section{ABSTRACT}

\section{BACKGROUND}

Thalassemia syndromes are most common monogenic disorders which can be inherited by children from their parents. This study aimed to evaluate the correlation of cytogenetic (1p36 deletion), molecular (common mutations) and clinical findings such as haematologic parameters, age at presentation, nutritional status and transfusion requirements with $\beta$-thalassemia patients.

\section{METHODS}

In total, $140 \beta$-thalassemia patients were clinically classified into $\beta$-thalassemia major (TM) or intermedia (TI). The cytogenetic analysis for 1 p36 deletion was carried out in suspected patients with phenotypic dysmorphic, developmental delay and mental retardation by karyotyping. ARMS-PCR was performed to identify the common mutations in $\beta$-thalassemia patients. All data were analyzed by SPSS software.

\section{RESULTS}

Karyotyping was performed in $10 \beta$-Thalassemia patients for $1 \mathrm{p} 36 \mathrm{del}$. based on their physical appearance and intelligence; but, none of them were found to be positive for 1 p36 del. Total 101 (72.14\%) patients were of thalassemia major and 39 (27.86\%) were of thalassemia intermedia. Among the thalassemia major patients, 71 (70.30\%) have common mutation. In our study the IVS I- $5 \mathrm{G} \rightarrow \mathrm{C}$ mutation was most common 62 $(87.32 \%)$ in thalassemia major patients. The clinical parameters such as $\mathrm{Hb}(\mathrm{gm} / \mathrm{dl})$, $\mathrm{HbA} 2(\%), \mathrm{HbF}(\%), \mathrm{MCV}(\mathrm{fL}), \mathrm{MCH}(\mathrm{pg})$ and $\mathrm{MCHC}(\mathrm{gm} / \mathrm{dl})$ were significantly associated with $\beta$-Thalassemia major.

\section{CONCLUSIONS}

In $\beta$-Thalassemia patients, 1 p36 deletion was not observed. In our study, the IVS I-5 $\mathrm{G} \rightarrow \mathrm{C}$ mutation was the most common [62(87.32\%)]. There were significant differences on the age of first transfusion, $\mathrm{Hb}$ (gm/dl), HbA2 (\%), HbF (\%), MCV (fL), $\mathrm{MCH}(\mathrm{pg})$ and MCHC (gm/dl) in between $\beta$-Thalassemia major and intermedia.

\section{KEY WORDS}

Cytogenetics, Thalassemia, Mental Retardation, Mutation, Genetic Disorder

\begin{abstract}
Corresponding Author: Dr. Nishant Verma,

Department of Paediatric, King George's Medical University, Lucknow, Uttar Pradesh, India. E-mail: drnishantaiims@gmail.com

DOI: $10.14260 / \mathrm{jemds} / 2019 / 746$

Financial or Other Competing Interests: None.

How to Cite This Article:

Nigam N, Verma $N$, Agrawal M, et al. Correlation of cytogenetic, molecular and clinical findings in thalassemia patients at a tertiary care hospital. J. Evolution Med. Dent. Sci. 2019;8(46):3441-3448, DOI: 10.14260/jemds/2019/746
\end{abstract}

Submission 05-10-2019,

Peer Review 29-10-2019,

Acceptance 05-11-2019,

Published 18-11-2019. 


\section{BACKGROUND}

Thalassemia is one of the most common monogenic disorders in the world but it is a very heterogeneous disease at the clinical and molecular levels.[1-4] This is an inherited group of haemolytic anaemias, including beta-thalassemia and alphathalassemia, caused by absent or reduced production of the globin chains of haemoglobin (hb). ${ }^{[5-6]}$

These alterations depend on the degree of imbalances formed between $\alpha$ - and non- $\alpha$-globin chains synthesis. ${ }^{[6]}$ The incidence of this disease is high in many parts of the Indian subcontinent. [7] The $\beta$ thalassaemias pose a significant health burden in India. The average prevalence of $\beta$ thalassemia carriers is $3-4 \%$ which translates to 35 to 45 million carriers in our multi-ethnic and culturally and linguistically diverse population of 1.21 billion people which also includes around 8\% of tribal groups according to the Census of India 2011. Several ethnic groups have a much higher prevalence (4-17\%). ${ }^{[8,9]}$

The haematological and clinical spectrum of betathalassemia is very wide (Mild, intermedia and major) producing a diverse spectrum of clinical manifestations. So, the determination of factors causing such different clinical presentation of the disease has clinical importance. The underlying genetic mutation is one of the determinants of clinical presentation of beta thalassemia.[10]

$\beta$-Thalassemia major patients have severe anaemia, microcytic and hypochromic anaemia and hepatosplenomegaly. These thalassemia patients generally come to medical attention within the first two years of life.[11] Previously, there was no specific arrangement of congenital abnormalities associated with thalassemia and no constitutional chromosomal abnormalities have been identified in $\beta$-Thalassemia patients. Recently, a study reported that thalassemia patients with mental retardation was associated with microcephaly and congenital cataract, both having loss p36 position in chromosome 1 in Indian population. ${ }^{[12]}$ The $\mathrm{p} 36$ short arm deletion on chromosome 1 , associated in a syndrome with mental retardation and multiple congenital anomalies.[13] This monosomy $1 \mathrm{p} 36$ is the most common (Occurring in 1 in 5,000 births) terminal deletion syndrome in humans.[14,15]

Thalassemia major or thalassemia intermedia may develop by homozygous or compound heterozygous mutation. Thalassemia major are generally diagnosed within 2 years of age and regular blood transfusions is required for survival.[16] Whereas intermedia are diagnosed later and do not require regular blood transfusion for survival. The clinical indices of $\beta$ thalassaemias are greatly variable such as mild (Silent) mutations, mild hypochromic anaemia, moderate and severe lifetime transfusion-dependent anaemia and multi organ involvement.[17]

Presently, the molecular basis (Mutation) of $\beta$-thalassemia has been studied worldwide.[10] Maximum thalassemia mutations are contributed by small deletions, insertions or point mutations within the coding regions (CDS: coding sequence) and the exon-intron junctions. ${ }^{[10]}$ The prevalence of $\beta$-thalassemia trait was $2.78 \%$ and range from 1.48 to $3.64 \%$ in different states. HbE trait was mainly seen in Dibrugarh in Assam (23.9 \%) and Kolkata in West Bengal (3.92 \%).[18] Now, more than 200 mutations have been known in $\beta$-thalassemia patients in chromosome $11, \beta$-globin gene, resulting in a total or partial deficit of the synthesis $\beta$-globin chain and reduce of the production of adult haemoglobin ( $\mathrm{HbA}) .{ }^{[6,11]}$ The most common mutations for $\beta$-thalassemia in India are IVS I-5 (GC), IVS I-1 (G-T), Co 41/42 (-CTTT), Co 8/9 (+G) and 619 bp del.

Our aim was to find out further information regarding anaemia since there are previously reported cases of anaemias associated with this $1 \mathrm{p} 36$ region with genetic disorder which is characterized by haematological abnormalities, other shows the 'putative tumour suppressor gene' in chronic myelocytic leukemia and the other is one inherited erythroblastopenia, commonly known as 'Diamond-Blackfan anaemia' (DBA), caused by mutation in the gene encoding ribosomal protein L11 (RPL11). In this study we also explore the correlation of cytogenetic, molecular and clinical findings such as haematologic parameters, age at presentation, nutritional status and transfusion requirements with $\beta$-thalassemia patients. Our data show the genotype-phenotype correlation of each mutation.

\section{METHODS}

\section{Patient Selection}

One hundred and forty beta-thalassemia patients who attended the Thalassemia Clinic, Department of Paediatrics, King George's Medical University, Lucknow were registered in this study after the haematological confirmation of thalassemia. Informed written consent was obtained from patients, as per the institute guidelines. The sample size was taken based on the convenience of the study. The study protocol confirms to the ethical guidelines of the 1975 Declaration of Helsinki. This study was approved by Institutional ethical committee (No. 69/Ethics/R.Cell-17) at K. G. Medical University, Lucknow. All beta thalassemia patients, who were being transfused and managed for the clinical symptoms and manifestation of the disease were included in the study. Any unconfirmed blood transfusion dependent children were excluded from the study. Beta-thalassemia patients were clinically classified into major and intermedia on the based criteria such as age at presentation, average $\mathrm{Hb}$ level at the steady state and transfusion frequency history, $\mathrm{HbE}$ and HbS. A whole clinical history along with blood transfusion events were recorded. Patients were also examined for growth parameters (Height, Weight, and Nutrition). The cytogenetics analysis was carried out in suspected patients with phenotypic dysmorphic, developmental delay and mental retardation.

\section{Karyotyping for Chromosomal Abnormalities}

Karyotypes were described according to the International System for Cytogenetic Nomenclature (ISCN 2005). The blood sample was collected in heparin vials. $500 \mathrm{ul}$ of blood sample was culture in $5 \mathrm{ml}$ of media from (Gibco PB Max) up to 70 hours. $5 \mathrm{ml}$ of exponentially growing cells were treated with $30 \mu \mathrm{l}$ of Colcemid (10 $\mu \mathrm{g} / \mathrm{ml}$ Gibco KaryoMax) and incubated for 1 hour at $37^{\circ} \mathrm{C}$ and centrifuge at $1000 \mathrm{rpm}$ for 10 minutes. Discard the supernatant suspend the cells in $5 \mathrm{ml}$ of hypotonic solution and incubate at $37^{\circ} \mathrm{C}$ for 30 minutes. Cells were fixed by the addition of $5 \mathrm{ml}$ of fixative which consist of 3:1 cold methanol/acetic acid mixture. The fixation was repeated 3 times, and centrifuged after each addition. Metaphase cells were stored at $-20^{\circ} \mathrm{C}$ in $1 \mathrm{ml}$ fixative. This cold suspension of 
metaphase cells was dropped from $30 \mathrm{~cm}$ height onto a horizontal microscopic slide and the fixative was allowed to evaporate at $56^{\circ} \mathrm{C}$ temperature on a hot plate. Trypsin powder ( $0.15 \mathrm{gm})$ was added in $50 \mathrm{ml}$ of phosphate buffer saline (PBS) solution. Depending on the ageing of the slide, dip the slides in trypsin solution for 3 to 5 seconds. Dip the slides in cold normal saline to stop trypsin activity and the wash under tap water. Keep the slides in Giemsa solution for 5 to 7 minutes and wash in tap water. Slide was covered with a $24 \times 60 \mathrm{~mm}$ cover glass and sealed with DPX solution. Metaphase imaging was done on a Nikon eclipse 90i inverted microscope (Nikon Microsystems, Japan). Per slide a representative number of pictures was taken for analysis (At least 25 spreads per sample). Evaluation of chromosome counts per cell in each picture was done using the Genikon software.

\section{Hematological Analysis}

Haemoglobin, red blood cell counts, and red cell indices, were assessed. Automated high-performance liquid chromatography (HPLC) system was used for analysing the haemoglobin variants. This system utilized doublewavelength detection (416 and $690 \mathrm{nM}$ ). This cationic exchange column chromatography enables qualitative determinations of $\mathrm{Hb} \mathrm{A} 2, \mathrm{Hb} \mathrm{F}$ and abnormal haemoglobins in 6.5 minutes on a haemolysate prepared from $5 \mathrm{ml}$ of venous blood.

\section{Blood Collection and DNA Extraction}

The blood sample of thalassemia patients were collected in EDTA vials. Genomic DNA was isolated from blood by standard commercial kits (QIAamp DNA Mini Kit) according to the manufacturer's instructions.

\section{Molecular Analysis}

Multiplex ARMS PCR was used to amplify different fragments corresponding to the coding regions of the concerned genes for $\beta$ thalassemia mutation. PCR analysis was performed first for five common mutations. These mutations are IVS I-5 (G-C), IVS I-1 (G-T), Co 41/42 (-CTTT), Co 8/9 (+G) and -619bp deletion. We used ARMS-PCR for each mutation in the following manner: the DNA was amplified using a set of three primers fitted to amplify either the wild type or mutated allele as described by Newton et al. (1989) [19].

\begin{tabular}{|c|c|c|c|}
\hline Mutation & Nucleotide Sequence & $\begin{array}{l}\text { Tm } \\
\left({ }^{0} \mathrm{C}\right)\end{array}$ & $\begin{array}{l}\text { Product } \\
\text { Size }\end{array}$ \\
\hline IVS1-1 M & 5'TTAAACCTGTCTTGTAACCTTGATACGAAA & 56 & $281 \mathrm{bp}$ \\
\hline IVS1-5 M & $5^{\prime}$-СTCСTTAAACCTGTCTTGTAACCTTGTTAG & 59 & $285 \mathrm{bp}$ \\
\hline $\mathrm{Cd} 8 / 9 \mathrm{M}$ & 5'CCTTGCCCCACAGGGCAGTAACGGCACACC & 70 & $225 \mathrm{bp}$ \\
\hline $\mathrm{Cd} 41 / 42 \mathrm{M}$ & 5'-GAGTGGACAGATCCCCAAAGGACTCAACCT & 64 & $439 \mathrm{bp}$ \\
\hline $619 \mathrm{bpdel}$ & 5'-GAG TCA AGG CTG AGA GAT GCA GGA-3 & 61 & 242 bp \\
\hline Internal Control C1 & 5'-CAATGTATCATGCCTCTTTGCACC & 56 & \multirow{4}{*}{$861 \mathrm{bp}$} \\
\hline Internal Control C2 & 5'-GAGTCAAGGCTGAGAGATGCAGGA & 59 & \\
\hline Reverse Primer B1 & 5'-ACCTCACCCTGTGGAGCCA & 58 & \\
\hline Reverse Primer B2 & 5' -CCССТTCСТATGACATGAACTTAA & 54 & \\
\hline \multicolumn{4}{|c|}{ Table 1. List of the Primers } \\
\hline
\end{tabular}

\section{Statistical Analysis}

Continuous data were summarized as Mean \pm SD while discrete (categorical) data in percentage. Categorical variables in two groups were compared using the Chi-square test. Continuous variables in two groups were compared by t-test. The $\mathrm{p}$-value $<0.05$ was considered significant. All the analysis was carried out using SPSS 16.0 version (Chicago, Inc., USA).

\section{RESULTS}

One hundred forty beta-thalassemia patients who attended the Thalassemia Clinic, Department of Paediatrics, King George's Medical University, Lucknow were registered in this study. Basic characteristics of patients are shown in Table 2. Range of age among thalassemia patients was between 4 and 408 months Mean age of patients was $40.19 \pm 53.00$ months. Out of 140 beta thalassemia patients, 101 patients had beta thalassemia major and 39 patients had beta thalassemia intermedia.

\begin{tabular}{|c|c|c|c|c|c|c|}
\hline & n & Mean & Median & SD & Min & Max \\
\hline \multicolumn{7}{|c|}{ Age (Months) } \\
\hline Age (months & 140 & 40.19 & 18.00 & 53.00 & 4.00 & 408.00 \\
\hline Age 1-12 months & 56 & 8.91 & 9.00 & 2.87 & 4.00 & 12.00 \\
\hline Age 13-24 months & 33 & 20.73 & 24.00 & 3.64 & 12 & 24.00 \\
\hline Age 24-60 months & 25 & 45.36 & 48.00 & 11.50 & 30 & 60.00 \\
\hline Age > 60 months & 26 & 127.31 & 108.00 & 69.61 & 66 & 408.00 \\
\hline Gender & $\mathbf{n}$ & \% & - & - & - & - \\
\hline Male & 101 & 72.14 & - & - & - & - \\
\hline Female & 39 & 27.86 & - & - & - & - \\
\hline Religion & & & & & & \\
\hline Hindu & 91 & 65.0 & - & - & - & - \\
\hline Muslim & 49 & 35.0 & - & - & - & - \\
\hline Clinical Investigation & $\mathbf{n}$ & Mean & Median & SD & Min & Max \\
\hline Hb & 135 & 5.11 & 5.10 & 1.37 & 1.70 & 9.30 \\
\hline HbA2 & 140 & 6.23 & 3.1 & 12.94 & 0.00 & 81.10 \\
\hline HbF & 140 & 54.55 & 52.75 & 30.87 & 0.30 & 97.80 \\
\hline MCV & 140 & 69.36 & 68.95 & 11.85 & 6.50 & 99.50 \\
\hline MCH & 140 & 24.29 & 23.75 & 4.95 & 14.40 & 46.40 \\
\hline MCHC & 140 & 35.11 & 34.70 & 5.19 & 17.60 & 49.10 \\
\hline RDW \% & 140 & 32.27 & 33.20 & 7.41 & 0.90 & 46.50 \\
\hline Ferritin Blood & 132 & 1764.52 & 1705.0 & 688.98 & 193.80 & 4495.0 \\
\hline Table 2. Baseline Characteristics of Beta-Thalassemia Patients \\
\hline
\end{tabular}

The mean age of first visit of $\beta$-Thalassemia patients were $34.40 \pm 41.37$ and $55.21 \pm 73.83$ months in major and intermedia, respectively in our Thalassemia clinics. Most of $\beta$ Thalassemia patients $(67.32 \%)$ were visit within 24 months. Age of first transfusion was $9.59 \pm 10.44$ and $39.00 \pm 36.61$ in $\beta$ Thalassemia Major and $\beta$-Thalassemia Intermedia, respectively. The mean age of first visit, age of first transfusion, height $(\mathrm{cm})$, weight $(\mathrm{kg})$ and clinical parameters $(\mathrm{Hb}, \mathrm{HbA} 2$, $\mathrm{HbF}, \mathrm{MCV}, \mathrm{MCH}$ and MCHC) were significant different in between $\beta$-Thalassemia Major and $\beta$-Thalassemia Intermedia (Table 3 ). The $\beta$-Thalassemia was more common in male, $77.23 \%$ in major and $58.97 \%$ in intermedia. Out of 101 , total $66(65.35 \%)$ patients were belong to Hindu religion whereas $40(34.65 \%)$ patients were belong to Muslim religion in $\beta$ Thalassemia Major. Whereas $64.10 \%$ Hindu and $35.90 \%$ Muslim religion in $\beta$-Thalassemia intermedia.

The distribution of beta-thalassemia in major 101 (72.14\%) and intermedia $39(27.86 \%)$ patients (Table 4$)$. In beta-thalassemia in major $71(70.30 \%)$, the common mutations are further classified in to IVS $1-1 \mathrm{G} \rightarrow \mathrm{T}$, IVS I- $5 \mathrm{G} \rightarrow \mathrm{C}$, Cd 8/9 +G, Cd 41/42 (-TCTT) and 619 bp deletion. Out of 71, maximum number of patients $62(87.32 \%)$ have IVS1-5 G-C common mutation, whereas $7.04 \%$ in $\mathrm{Cd} 8 / 9+\mathrm{G}, 2.82 \%$ and $1.41 \%$ in IVS $1-1 \mathrm{G} \rightarrow \mathrm{T}$ and 619 del each. Whereas, in $\beta$ Thalassemia intermedia 39 (29.70\%), out of $25,2(5.12 \%)$ have IVS1-5 G-C common mutation, Whereas $5(12.82 \%)$ in $\mathrm{HbS}, 12$ (30.77 \%) in $\mathrm{HbE}, 1$ (2.65\%) in HbS+ IVS I-5 G $\rightarrow$ C, 3 $(7.69 \%)$ in $\mathrm{HbE}+$ IVS $\mathrm{I}-5 \mathrm{G} \rightarrow \mathrm{C}$ and $2(5.13 \%)$ in $\mathrm{HbE}+\mathrm{Cd} 41 / 42$ (-TCTT). 


\begin{tabular}{|c|c|c|c|c|c|}
\hline \multirow[b]{2}{*}{ Age Months) } & \multicolumn{2}{|c|}{$\begin{array}{l}\beta \text {-Thalassemia } \\
\text { Major }(n=101)\end{array}$} & \multicolumn{2}{|c|}{$\begin{array}{c}\beta \text {-Thalassemia } \\
\text { Intermedia }(n=39)\end{array}$} & \multirow[t]{2}{*}{$\mathbf{p}$} \\
\hline & Mean & SD & Mean & SD & \\
\hline \multirow[t]{2}{*}{ Age (months } & 34.40 & 41.37 & 55.21 & 73.83 & $0.037^{*}$ \\
\hline & $\mathbf{n}$ & $\%$ & $\mathbf{n}$ & $\%$ & \\
\hline Age 1-12 months & 42 & $41.58 \%$ & 14 & $35.90 \%$ & \multirow{4}{*}{$0.045^{*}$} \\
\hline Age 13-24 months & 26 & $25.74 \%$ & 7 & $17.95 \%$ & \\
\hline Age 24-60 months & 20 & $19.80 \%$ & 5 & $12.82 \%$ & \\
\hline Age $>60$ months & 13 & $12.87 \%$ & 13 & $33.33 \%$ & \\
\hline \multirow{2}{*}{$\begin{array}{l}\text { Age of First Transfusion } \\
\text { (month) }\end{array}$} & Mean $(n=101)$ & SD & Mean $(n=27)$ & SD & \\
\hline & 9.59 & 10.44 & 39.00 & 36.61 & $<0.001^{*}$ \\
\hline Weight (kg) & 8.10 & 5.41 & 16.74 & 7.31 & $<0.001^{*}$ \\
\hline Height $(\mathrm{cm})$ & 74.49 & 17.16 & 106.59 & 22.56 & $<0.001^{*}$ \\
\hline Gender & $\mathrm{n}$ & $\%$ & $\mathrm{n}$ & $\%$ & \\
\hline Male & 78 & $77.23 \%$ & 23 & $58.97 \%$ & \multirow[b]{2}{*}{0.051} \\
\hline Female & 23 & $22.77 \%$ & 16 & $41.03 \%$ & \\
\hline \multicolumn{6}{|l|}{ Religion } \\
\hline Hindu & 66 & $65.35 \%$ & 25 & $64.10 \%$ & \multirow{3}{*}{0.890} \\
\hline Muslim & 35 & $34.65 \%$ & 14 & $35.90 \%$ & \\
\hline Clinical Investigation & Mean & SD & Mean & SD & \\
\hline $\mathrm{Hb}(\mathrm{gm} / \mathrm{dl})$ & 4.86 & 1.34 & 5.77 & 1.21 & $<0.001^{*}$ \\
\hline $\mathrm{HbA2}(\%)$ & 3.55 & 4.51 & 13.19 & 22.13 & $<0.001^{*}$ \\
\hline $\mathrm{HbF}(\%)$ & 63.14 & 29.73 & 32.32 & 21.38 & $<0.001^{*}$ \\
\hline MCV (fL) & 71.20 & 9.74 & 64.60 & 15.23 & $0.003^{*}$ \\
\hline $\mathrm{MCH}(\mathrm{pg})$ & 25.34 & 4.77 & 21.57 & 4.37 & $<0.001^{*}$ \\
\hline $\mathrm{MCHC}(\mathrm{gm} / \mathrm{dl})$ & 36.045 & 4.881 & 32.69 & 5.24 & $<0.001^{*}$ \\
\hline Ferritin Blood (ng/ml) & 1810.8 & 682.06 & 1613.8 & 701.04 & 0.165 \\
\hline \multicolumn{6}{|c|}{$\begin{array}{c}\text { Table 3. Comparison of Baseline Characteristics in Beta-Thalassemia } \\
\text { Major and Intermedia Patients }\end{array}$} \\
\hline
\end{tabular}

\begin{tabular}{|c|c|c|}
\hline Mutation & $\mathbf{n}$ & $\%$ \\
\hline \multicolumn{3}{|c|}{$\beta$-Thalassemia major $(n=101)$} \\
\hline Common Mutation & 71 & 70.30 \\
\hline IVS 1-1 G $\rightarrow$ T & 1 & 1.41 \\
\hline IVS I-5 G $\rightarrow$ C & 62 & 87.32 \\
\hline $\mathrm{Cd} 8 / 9+\mathrm{G}$ & 2 & 2.82 \\
\hline Cd 41/42 (-TCTT) & 5 & 7.04 \\
\hline 619 del & 1 & 1.41 \\
\hline Unidentified Mutation & 30 & 29.70 \\
\hline \multicolumn{3}{|c|}{$\beta$-Thalassemia intermedia $(n=39)$} \\
\hline Common Mutation & 25 & 64.10 \\
\hline IVS I-5 G $\rightarrow$ C & 2 & 5.12 \\
\hline \multicolumn{3}{|l|}{ Combined Mutation } \\
\hline $\mathrm{HbS}$ & 5 & 12.82 \\
\hline $\mathrm{HbE}$ & 12 & 30.77 \\
\hline $\mathrm{HbS}+\mathrm{IVS} \mathrm{I}-5 \mathrm{G} \rightarrow \mathrm{C}$ & 1 & 2.65 \\
\hline $\mathrm{HbE}+\mathrm{IVS} \mathrm{I}-5 \mathrm{G} \rightarrow \mathrm{C}$ & 3 & 7.69 \\
\hline $\mathrm{HbE}+\mathrm{Cd} 41 / 42(-\mathrm{TCTT})$ & 2 & 5.13 \\
\hline Unidentified Mutation & 14 & 35.90 \\
\hline
\end{tabular}

Table 4. Genotypic Distribution of $\beta$-Thalassemia Major Patients ( $n=101)$

On the basis of mean fetal haemoglobin (Haemoglobin F or $\mathrm{HbF}$ ), the distribution of types of mutation, MCV and MCH in $\beta$ Thalassemia major patients are shown in Table 5 . Total $45.54 \% \beta$-thalassemia major patients have less than 63.14 fetal haemoglobin (Haemoglobin $\mathrm{F}$ or $\mathrm{HbF}$ ) with $63.04 \%$ common mutation and $36.96 \%$ unidentified mutation, in which $86.96 \%$ with $\mathrm{MCV} \leq 80$ and $73.91 \%$ have $\mathrm{MCH} \leq 27$. Whereas $54.46 \% \beta$-thalassemia major patients have equal or greater than 63.14 fetal haemoglobin (Haemoglobin $\mathrm{F}$ or $\mathrm{HbF}$ ) with $76.36 \%$ common mutation and $23.64 \%$ unidentified mutation, in which $72.73 \%$ with $\mathrm{MCV} \leq 80$ and $70.91 \%$ have $\mathrm{MCH} \leq 27$. On the basis of $\mathrm{HbF}$ level, the distribution of patients was comparable in common and unidentified mutation, moreover, slightly higher number of $\beta$-Thalassemia major patients have $\geq 63.14 \mathrm{HbF}$ level with a smaller number of patients with $\mathrm{MCV} \leq 80$ and $\mathrm{MCH} \leq 27$. In this study, common mutation in beta thalassemia patients have greater $\mathrm{HbF}$ value compare to unidentified mutation.

\begin{tabular}{|c|c|c|c|c|c|}
\hline \multirow[t]{2}{*}{ Hb F } & \multirow[t]{2}{*}{$\begin{array}{c}\text { No. of Patients } \\
\text { n (\%) }\end{array}$} & \multicolumn{2}{|c|}{$\beta$-Thalassemia Major } & \multirow{2}{*}{$\begin{array}{l}\text { MCV } \\
\leq 80\end{array}$} & \multirow{2}{*}{$\begin{array}{l}\text { MCH } \\
\leq 27\end{array}$} \\
\hline & & $\begin{array}{l}\text { Common } \\
\text { Mutation }\end{array}$ & Unidentified & & \\
\hline$<63.14$ & $46(45.54 \%)$ & $29(63.04 \%)$ & $17(36.96 \%)$ & $\begin{array}{c}40 \\
(86.96 \%)\end{array}$ & $\begin{array}{c}34 \\
(73.91 \%)\end{array}$ \\
\hline$\geq 63.14$ & $55(54.46 \%)$ & $42(76.36 \%)$ & $13(23.64 \%)$ & $\begin{array}{c}40 \\
(72.73 \%) \\
\end{array}$ & $\begin{array}{c}39 \\
(70.91 \%)\end{array}$ \\
\hline & $\mathrm{p}$-Value & \multicolumn{2}{|c|}{0.147} & 0.081 & 0.074 \\
\hline
\end{tabular}

Table 5. Distribution Types of Mutation, MCV and MCH on the Basis of Mean HbF in $\beta$-Thalassemia Major

On the basis of mean fetal haemoglobin (Haemoglobin F or $\mathrm{HbF}$ ), the distribution types of mutation, MCV and MCH in $\beta$ Thalassemia intermedia patients are shown in Table 6. Total $53.85 \% \beta$-thalassemia intermedia patients have less than 32.32 fetal haemoglobin (Haemoglobin F or $\mathrm{HbF}$ ) with $71.43 \%$ common mutation and $28.57 \%$ unidentified mutation, in which $85.71 \%$ with $\mathrm{MCV} \leq 80$ and $90.48 \%$ have $\mathrm{MCH} \leq 27$. Whereas $46.15 \% \quad \beta$-thalassemia intermedia patients have equal or greater than 32.32 fetal haemoglobin (Haemoglobin $\mathrm{F}$ or $\mathrm{HbF}$ ) with $55.56 \%$ common mutation and $44.44 \%$ unidentified mutation, in which $94.94 \%$ with $\mathrm{MCV} \leq 80$ and 83.33\% have $\mathrm{MCH} \leq 27$. On the basis of $\mathrm{HbF}$ level, the distribution of patients was comparable in common and unidentified mutation, moreover, slightly higher number of $\beta$ Thalassemia intermedia patients have $<32.32 \mathrm{HbF}$ level.

\begin{tabular}{|c|c|c|c|c|c|}
\hline \multirow[t]{2}{*}{ Hb F } & \multirow[t]{2}{*}{$\begin{array}{c}\text { No. of Patient's } \\
n(\%)\end{array}$} & \multicolumn{2}{|c|}{$\begin{array}{c}\beta \text {-Thalassemia } \\
\text { Intermedia }(n=39)\end{array}$} & \multirow[t]{2}{*}{$\begin{array}{l}\text { MCV } \\
\leq 80 \\
\end{array}$} & \multirow[t]{2}{*}{$\begin{array}{l}\text { MCH } \\
\leq 27 \\
\end{array}$} \\
\hline & & $\begin{array}{l}\text { Common } \\
\text { Mutation }\end{array}$ & Unidentified & & \\
\hline$<32.32$ & $21(53.85 \%)$ & $15(71.43 \%)$ & $6(28.57 \%)$ & $\begin{array}{c}18 \\
(85.71 \%) \\
\end{array}$ & $\begin{array}{c}19 \\
(90.48 \%)\end{array}$ \\
\hline$\geq 32.32$ & 18 (46.15\%) & $10(55.56 \%)$ & $8(44.44 \%)$ & $\begin{array}{c}17 \\
(94.94 \%) \\
\end{array}$ & $\begin{array}{c}15 \\
(83.33 \%) \\
\end{array}$ \\
\hline
\end{tabular}

Table 6. Distribution Types of Mutation, MCV and MCH on the Basis of Mean HbF in $\beta$-Thalassemia Intermedia

\begin{tabular}{|c|c|c|c|c|}
\hline Test & Sensitivity & Specificity & PPV & NPV \\
\hline $\mathrm{HbA2}(\%)$ & $87.3 \%$ & $42.0 \%$ & $70.4 \%$ & $67.7 \%$ \\
\hline $\mathrm{HbF}(\%)$ & $93.3 \%$ & $43.8 \%$ & $55.4 \%$ & $89.7 \%$ \\
\hline $\mathrm{MCV}(\mathrm{fL})$ & $72.9 \%$ & $28.8 \%$ & $43.0 \%$ & $59.0 \%$ \\
\hline MCH (pg) & $85.4 \%$ & $35.6 \%$ & $41.4 \%$ & $81.1 \%$ \\
\hline Table 7. Sensitivity, Specificity, NPV and PPV of HbA2, HbF, MCV and \\
MCH to Predict $\beta$-Thalassemia Major \\
\hline
\end{tabular}
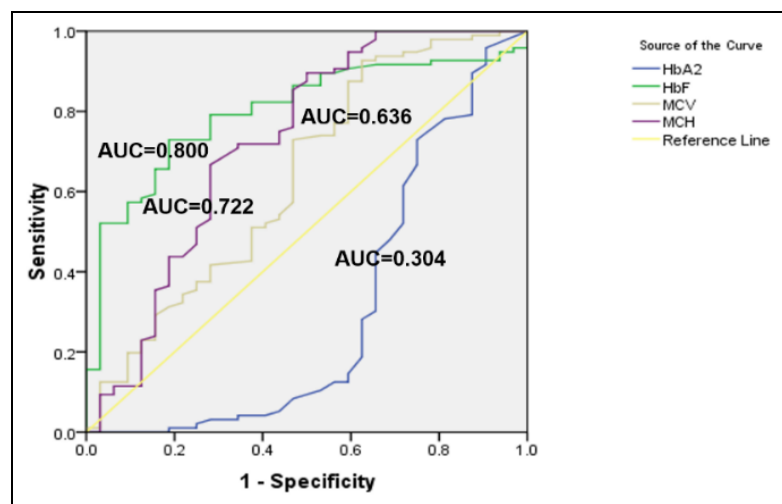

Figure 1. Receiver Operating Characteristic (ROC) Curve Analysis of HbA2, HbF, MCV and MCH in $\beta$-Thalassemia Major Patients. Each Receiver Characteristic Curve is Expressed as a Solid Line. AUC: Area Under the Curve

The sensitivity, specificity, positive and negative predictive values (PPV and NPV) were used to analyse the $\mathrm{HbA2}, \mathrm{HbF}$, MCV and MCH (Table 7). The cut-off value for HbA2, HbF, MCV and $\mathrm{MCH}$ were $3.2,63.14,71.20$ and 25.34 , respectively to make a diagnosis of $\beta$-Thalassemia major. With these cut-off 
values, $\mathrm{HbF}$ and $\mathrm{HbA} 2$ had greater sensitivity of 93.3\%, 87.3\% and specificity of $43.8 \%$ and $42.0 \%$, respectively in the diagnosis of $\beta$-Thalassemia major. The $\mathrm{HbA} 2, \mathrm{HbF}, \mathrm{MCV}$ and $\mathrm{MCH}$ were showed significantly large area under the curve (AUC=0.487) on the ROC curve (Fig. 1).

Out of 140 beta thalassemia patients, karyotyping was performed only in 10 patients for $1 \mathrm{p} 36$ del. based on their physical appearance and intelligent. Quotient only 10 patients were taken into consideration for $1 \mathrm{p} 36 \mathrm{del}$, but none of them was found to be positive for 1 p36 deletion. They all were normal (Fig. 2).

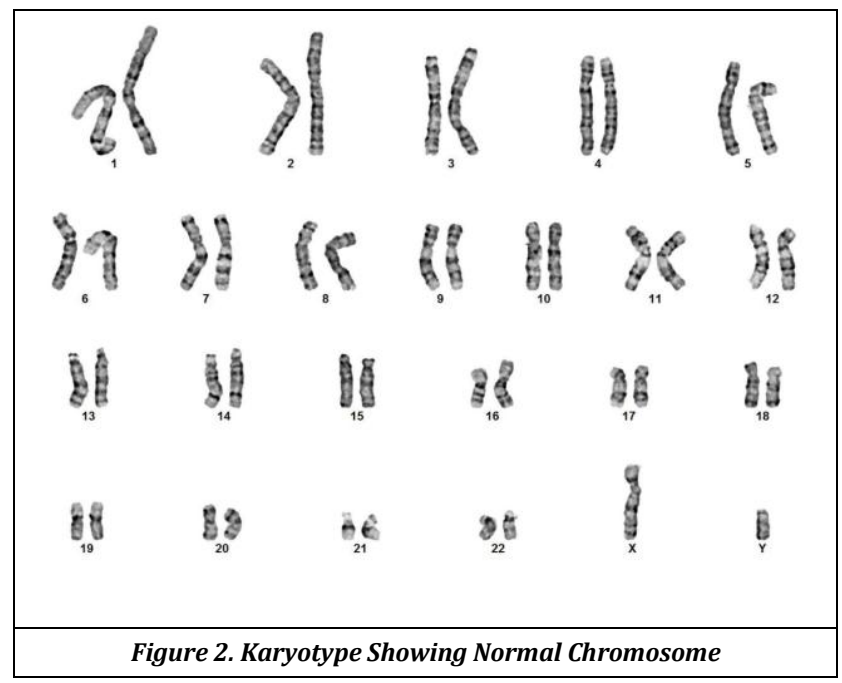

\section{DISCUSSION}

Beta-Thalassemia is one of the most common monogenic disorders which can be transmitted from parents to their children. The type of $\beta$-globin gene mutation mainly affects the severity of beta-thalassemia disease. In this study we revealed the distribution of the $\beta$-globin gene mutations affecting the beta-thalassemia along with phenotype-genotype correlation in North Indian paediatrics population. Beta-thalassemia is the most important thalassemia problem in India. It can be linked with numerous clinical phenotypes ranging from thalassemia intermedia to thalassemia major. In our study, all thalassaemic patients are from Uttar Pradesh state. The treatment facilities for thalassemia patients including transfusion, chelation and specialist should be made available at medical college/district hospitals in various part of the state due regions where there is high incidence of thalassemia so that the families don't have to migrate to bigger cities for treatment.

The cytogenetic analysis of a distal short arm deletion of chromosome with dysmorphic features, develop mental and growth delays with microcytic anaemia. By cytogenetic analysis, the deletion appeared to involve $1 \mathrm{p} 36.21$ and 1p36.3. Maximum deletions in chromosome 1p36 are novel mutations and occur during the formation of gametes (eggs or sperm), before fertilization. The patients with 1 p36 deletion their parents have a balanced/ symmetrical translocation. It means a 36' portion of chromosome one is relocated to another chromosome, when it happens, gametes are missing a portion of 36 in chromosome one during cell division before fertilization.[12]
In our study, we did not find $1 \mathrm{p} 36$ del. In beta thalassemia patients with phenotypic dysmorphic, developmental delay and mental retardation. Previously, De et al. (2014) revealed 46, XY, del (1) (p36.21) in the male who was also diagnosed as a 'beta thalassemia trait' and the other case was $46, \mathrm{XX}$, del (1) (p36.3) in the female who was diagnosed as a case of 'HbE-beta thalassemia'. Previously, Shapira et al. (1997) reported that the p36 deletion in chromosome one in a syndrome have multiple congenital abnormalities and mental delay.[13] This monosomy terminal deletion is most common (1 in 5,000 births) in humans. [14,15]

In our study, the maximum number $(67.32 \%)$ of beta thalassemia patients was 1-24 months of age with severe haemolytic anaemia. Similarly, the mean age was $17.2 \pm 19.9$ months, with $50 \%$ being diagnosed within the first year of life in an Indian cohort study.[20] Moreover, in 2016, a lower mean age of 3.7 years was reported in a similar study carried out in India.[21] Kattamis et al. (2005) reported that the age at which thalassemia presentation was noted to be 13.1 (2-36) months.[22] Our study was supported by Cao and Galanello, (2000),[23] who reported that the mean age of children with thalassemia to be $8.4 \pm 9.1$ months. Moreover, Modell and Berdoukas. ${ }^{[24]}$ also reported that the $60 \%$ of thalassemia patients with the mean age of 6 months had presented clinically in the first year of life. Thalassemia major is generally suspected in an infant younger than 24 months of age with severe microcytic anaemia and hepatosplenomegaly. Whereas Thalassemia intermedia shows at the later age with common but milder clinical findings.

In our study the Beta thalassemia was more prominent in male $(72.14 \%)$ with a male to female ratio of 2.6:1. Similarly, various previous Indian studies have reported a higher male preponderance of up to $68 \%$ and $69.5 \% .[25,26]$ Shah et al. (2010) found that in western India, 62\% (88 cases) of their studied cases with thalassemia were males, whereas 38\% (54 cases) were females.[27] In 2015, a higher male to female ratio (2.5:1) was reported among Indian children with thalassemia, with $71.4 \%$ being males. ${ }^{[20]}$ In addition, in 2016, a higher male predominance was reported among Saudi children with thalassemia as $70 \%$ were males, with a male to female ratio of 2.3:1.[28] Various other studies also reported that the male was slightly male predominance was detected in their study population. ${ }^{[21,29-31]} \mathrm{Al}-\mathrm{Kh}$ erbash et al. (2017) reported that the slight predominance was detected among as males represented $53.2 \%$ of the total studied cases, with a male to female ratio of 1.14:1.[32] In 2017, another study also reported that the male to female ratio 1.26 in thalassemia patients in Bangladesh. ${ }^{29]}$ A similar result was reported in an Indian study, in 2016, which found that $53.3 \%$ of their cases were males and $46.6 \%$ were females.[30] Zamani et al. (20015) reported that among their studied thalassaemic patients in Hamdan province in Iran, 54.9\% were males.[30] In addition, Bejaoui and Guirat, (2013) found that in Tunisia, $55.4 \%$ of male patients were thalassaemic, whereas $44.5 \%$ were female patients.[31]

In our study, the incident of beta thalassemia was greater in Muslim population. The Muslim population in Uttar Pradesh is $19.3 \%$ whereas $27.86 \%$ thalassemia patients are Muslim. This is mainly due the consanguinity among them. A comparably lower consanguinity rate $(53 \%)$ was detected in western India in 2010 as Shah et al. (2010 reported that the Muslim patients with thalassemia in their study were a result 
of a consanguineous marriage.[27] In Shiraz city, Iran, AsadiPooya and Doroudchi [33] reported that $49.5 \%$ of thalassaemic patients were a result of cousin marriages. In 2016, consanguineous marriage was detected in $26.6 \%$ of the parents of thalassaemic Indian children.[21]

In this study the total $101(72.14 \%)$ patients are thalassemia major and 39 (27.86\%) are thalassemia intermedia. Out of 101 patients are thalassemia major, total 71 $(70.30 \%)$ have common mutation. In our study the IVS I-5 $\mathrm{G} \rightarrow \mathrm{C}$ mutation was most common $62(87.32 \%)$, whereas 2 (2.82\%) Cd 8/9, 5 (7.04\%) Cd41/42 and 1 (1.41\%) IVS $1-1$ and $619 \mathrm{bp}$ del in thalassemia major patients. In this study, out of 39 beta thalassemia intermedia patients, total $25(64.10 \%)$ have common, $\mathrm{HbS}$ and $\mathrm{HbE}$ mutation. The $\mathrm{HbE}$ mutation was commonly found in intermedia $17(68.0 \%)$, whereas 6 (24.0\%) and 1 (4.0\%) IVS 1-5. Similarly, Shah et al. (2017) reported that the $92+5 \mathrm{G}>\mathrm{C}$ (IVS-1-5) mutation is the maximum in cases $(60.29 \%)$, of Rajasthan and Gujarat followed by deletion 619 bp.[34] Various previous studies reported the similar findings with others documented earlier in Gujarat, Maharashtra, and Rajasthan. ${ }^{[35-41]}$ Whereas, Hassan et al. (2013), reported that the cd26 (A-G) HbE and cd41/42 (-TTCT) were higher in their studies in Thailand population.[42] Thong et al. (2005) demonstrated that the cd41/42 (-TTCT) and IVS-2 654 (C-T) were greater in Chinese population. ${ }^{[43]}$ The incidence of these mutations does not seem to be related to sex, as our sex ratio was 1:1.13 (M:F). The variation in occurrence of these mutations is related to regional, ethical, migration, interracial marriages, study plan, and other factors as mentioned by others. ${ }^{[44,45]}$ The phenotype of compound heterozygous $\beta$-thalassemia can be intermedia or major. Individuals with $\beta$-thalassemia intermedia require RBC transfusion within few years after their birth, whereas $\beta$ thalassemia major would require medical treatment within two years.[36] The compound heterozygosity has led to $\beta^{+} \beta^{0}$ type causing $\beta$-thalassemia major. Usually in $\beta^{+} \beta^{0}$ type $\beta$ thalassemia, the $\mathrm{Hb}$ pattern shows HbA between 10 and $30 \%$, $\mathrm{HbF}$ of $70-90 \%$ and $\mathrm{HbA} 2$ of $2-5 \% .{ }^{[46]}$ Murali et al. (2004) have checked the prevalence of different mutations in different districts of Andhra Pradesh and Karnataka.[47] They can observe that IVS1+5G $>$ T mutation is the most popular around Andhra Pradesh and Karnataka. Krishna district of Andhra Pradesh has $100 \%$ IVS1 $+5 \mathrm{G}>\mathrm{T}$ mutation followed by Adilabad $87.5 \%$ and Hyderabad 77\%. Kirti et al. (2004) conducted a survey on different mutations present in different states in South India. ${ }^{[48]}$ They found that the IVS I-5 $(\mathrm{G} \rightarrow \mathrm{C})$ mutation prevalence is more, Andhra Pradesh IVS I-5 (G $\rightarrow \mathrm{C}$ ) 66.18\% Karnataka $45.76 \%$ Kerala $62.7 \%$ and Tamilnadu 56.6\%. Sinha et al. (2009), reported that the IVSI-5(G>C) is more $67.7 \%$ in beta thalassemia patients. ${ }^{[49]}$

In our study, the $\beta$-thalassemia major is characterized by reduced $\mathrm{Hb}$ level $(<4.86 \mathrm{~g} / \mathrm{dl})$, mean corpuscular volume (MCV) $71.2 \mathrm{fl}$ and mean corpuscular $\mathrm{Hb}(\mathrm{MCH}) 25.34 \mathrm{pg}$. Whereas intermedia is also characterized by reduced $\mathrm{Hb}$ level ( $<5.77 \mathrm{~g} / \mathrm{dl}$ ), mean corpuscular volume (MCV) $64.60 \mathrm{fl}$ and mean corpuscular $\mathrm{Hb}(\mathrm{MCH}) 21.57 \mathrm{pg}$.

Similarly, Galanello et al. (1979), reported that the $\beta$ Thalassemia major was characterized by reduced $\mathrm{Hb}$ level $(<7$ $\mathrm{g} / \mathrm{dl}$ ), mean corpuscular volume (MCV) $>50<70 \mathrm{fl}$ and mean corpuscular $\mathrm{Hb}(\mathrm{MCH})>12<20$ pg. ${ }^{[50]}$ Whereas, $\beta$ Thalassemia intermedia was characterized by $\mathrm{Hb}$ level between 7 and $10 \mathrm{~g} / \mathrm{dl}, \mathrm{MCV}$ between 50 and $80 \mathrm{fl}$ and MCH between 16 and $24 \mathrm{pg}$. Thalassemia minor was characterized by reduced MCV and $\mathrm{MCH}$, with increased $\mathrm{Hb}$ A2 level.[50]

In this study $\beta$-thalassemia major patients 46 (45.54\%) have less than 63.14 fetal haemoglobin, in which $29(63.4 \%)$ common mutation and 17 (36.96\%) unidentified mutation with $40(86.96 \%)$ patients have $\mathrm{MCV} \leq 80$ and $34(73.91 \%)$ patients have $\mathrm{MCH} \leq 27$. Whereas $55(54.56 \%)$ patients have $\geq$ 63.14 fetal haemoglobin, in which $42(76.36 \%)$ common mutation and $13(23.64 \%)$ unidentified mutation with 40 (72.73\%) patients have MCV $\leq 80$ and 39 (70.91\%) patients have $\mathrm{MCH} \leq 27$. This study shows that the beta thalassemia patients with common mutation have greater $\mathrm{HbF}$ value. Whereas the greater $\beta$-thalassemia major patients have less common mutation, $\mathrm{MCV} \leq 80$ and $\mathrm{MCH} \leq 27$ are slightly reduced in $\geq 63.14 \mathrm{HbF}$ group as compared to $<63.14 \mathrm{HbF}$. MCV of less than $80 \mathrm{fL}$ was reported in $96.5 \%$ cases of the $\beta$-thalassemia minor cases, $54.2 \%$ cases of sickle/ $\beta$-thalassemia, $100 \%(5 / 5)$ cases of $\mathrm{HbE}$ disease, $100 \%$ (2/2) cases of $\mathrm{HbE} / \beta$-thalassemia, $40 \%(2 / 5)$ cases of $\mathrm{HbE}$ traits, $100 \%(6 / 6)$ cases of $\mathrm{HbD}$ Punjab (100\%), and $76.9 \%$ cases in $\alpha$-thalassemia trait. An MCH value less than $27 \mathrm{pg}$ was observed in $100 \%$ of $\beta$ thalassemia minor cases, $92 \%$ of $\alpha$-thalassemia trait, $100 \%$ with sickle/ $\beta$-thalassemia cases, $100 \%$ of $\mathrm{HbE}$ disease, $100 \%$ of $\mathrm{HbE} / \beta$-thalassemia, $60 \%$ of $\mathrm{HbE}$ trait, and $83.3 \%$ of $\mathrm{HbD}$ Punjab. Similar results were reported earlier. ${ }^{[51,52]}$ The cases of $\beta$-thalassemia minor showed reduction in MCV and $\mathrm{MCH}$ values, and, thus, these parameters found to be important in diagnosis of $\beta$-thalassemia carriers. The degree of microcytosis and type of thalassemia mutation has shown wide variations in ranges of MCV.[52]

In our study, the cut-off values of $\mathrm{HbA2} 3.2 \%, \mathrm{HbF} 63.14 \%$, MCV $71.20 \mathrm{fl}$ and $\mathrm{MCH} 25.34 \mathrm{pg}$ were suggested to be associated with a high probability of $\beta$-thalassemia major. Our study was supported by a Indian study conducted by Bhukhanvala et al. (2013), who reported that the cut-off values of MCV $78.0 \mathrm{fl}$ or less, MCH $28 \mathrm{pg}$ or less, and $\mathrm{HbA}_{2}$ more than $3.8 \%$ for $\beta$-Thalassemia trait diagnosis. ${ }^{[53]}$ Previously, Soliman et al. (2014) found that the cut-off values of MCV 63.14 and MCH fl or less were suggested to be associated with a high probability of $\beta$-Thalassemia trait.[54] Though, Parthasarathy, (2012) observed that the cut-off values of MCV below $76 \mathrm{fl}$ was suggested to be associated with a high probability of $\beta$ Thalassemia trait in Indian population. ${ }^{[55]}$

\section{CONCLUSIONS}

The 1 p36 deletion in $\beta$-Thalassemia patients was not observed. In our study, the IVS I-5 G $\rightarrow$ C mutation was most common [62 (87.32\%)]. There were significant differences on the age of first transfusion, $\mathrm{Hb}$ (gm/dl), $\mathrm{HbA} 2(\%), \mathrm{HbF}(\%)$, MCV (fL), MCH (pg) and MCHC (gm/dl) between $\beta$ Thalassemia major and intermedia.

\section{ACKNOWLEDGEMENT}

We acknowledge Dr. Omesh Bharti, Professor, Padma Shri Awardee, State Epidemiologist, State Institute of Health and Family Welfare, Shimla, Himanchal Pradesh for his valuable suggestions. 


\section{REFERENCES}

[1] Steinber MH, Forget BG, Higgs DR, et al. Disorders of haemoglobin: genetics, pathophysiology and clinical management. J R Soc Med 2001;94(11):602-3.

[2] Thein SL. Genetic insights into the clinical diversity of beta thalassaemia. Br J Haematol 2004;124(3):264-74.

[3] Fucharoen S, Winichagoon P. Thalassemia and abnormal haemoglobin. Int J haematol 2002;76 Suppl 2:83-9.

[4] Schrier SL. Pathophysiology of thalassemia. Curr Opin haematol 2002;9(2):123-6.

[5] Luo HY, Chui DH. Diverse haematological phenotypes of $\beta$-thalassemia carriers. Ann N Y Acad Sci 2016;1368(1):49-55.

[6] Thein SL. The molecular basis of $\beta$-thalassemia. Cold Spring Harb Perspect Med 2013;3(5):a011700.

[7] Mondal SK, Mandal S. Prevalence of thalassemia and haemoglobinopathy in eastern India: a 10-year highperformance liquid chromatography study of 119,336 cases. Asian J Transfus Sci 2016;10(1):105-10.

[8] Madan N, Sharma S, Sood SK, et al. Frequency of $\beta$ thalassemia trait and other haemoglobinopathies in northern and western India. Indian J Hum Genet 2010;16(1):16-25.

[9] Colah RB, Gorakshakar A. Control of thalassemia in India. Thalassemia Rep 2014;4:84-9.

[10] Traivaree C, Monsereenusorn C, Rujkijyanont P, et al. Genotype-phenotype correlation among betathalassemia and beta-thalassemia/HbE disease in Thai children: predictable clinical spectrum using genotypic analysis. J Blood Med 2018;9:35-41.

[11] Danjou F, Anni F, Galanello R. Beta-thalassemia: from genotype to phenotype. Haematologica 2011;96(11):1573-5.

[12] De P, Chatterjee T, Chakravarty $S$, et al. Clinical presentation of two $\beta$-thalassemic Indian patients with 1p36 deletion syndrome: Case report. J Pediatr Genet 2014;3(3):175-81.

[13] Shapira SK, McCaskill C, Northrup H, et al. Chromosome 1p36 deletions: the clinical phenotype and molecular characterization of a common newly delineated syndrome. Am J Hum Genet 1997;61(3):642-50.

[14] Shaffer LG, Lupski JR. Molecular mechanisms for constitutional chromosomal rearrangements in humans. Annu Rev Genet 2000;34:297-329.

[15] Heilstedt HA, Ballif BC, Howard LA, et al. Physical map of 1p36, placement of breakpoints in monosomy $1 \mathrm{p} 36$ and clinical characterization of the syndrome. Am J Hum Genet 2003;72(5):1200-12.

[16] Cao A, Kan YW. The prevention of thalassemia. Cold Spring Harb Perspect Med 2013;3(2):a011775.

[17] Weatherall DJ, Clegg JB. The thalassaemia syndromes. $4^{\text {th }}$ edn. Oxford: Blackwell Science Ltd., 2001.

[18] Mohanty D, Colah RB, Gorakshakar AC, et al. Prevalence of $\beta$-thalassemia and other haemoglobinopathies in six cities in India: a multicentre study. J Community Genet 2013;4(1):33-42.
[19] Newton CR, Graham A, Heptinstall LE, et al. Analysis of any point mutation in DNA. The amplification refractory mutation system (ARMS). Nucleic Acids Res 1989;17(7):2503-16.

[20] Trehan A, Sharma N, Das R, et al. Clinicoinvestigational and demographic profile of children with thalassemia major. Indian J haematol Blood Transfus 2015;31(1):1216.

[21] Choudhari S, Behera MK. Chelation status \& clinical profile of thalassemic children attending paediatric clinics. Indian J Appl Res 2016;6(6):276-8.

[22] Kattamis C, Ladis V, Metaxatou-Mavromati A. haemoglobins $\mathrm{F}$ and $\mathrm{A} 2$ in Greek patients with $\beta$ and $\beta / \delta \beta$ thalassemia. In: Schmidt RM, edr. Abnormal haemoglobin's and thalassemia: diagnostic aspects. New York: Academic Press 2005: p. 209.

[23] Cao A, Galanello R. Effect of consanguinity on screening for thalassemia. N Engl J Med 2002;347(15):1200-2.

[24] Modell B, Berdoukas V. The clinical approach to thalassemia. New York: Grune \& Stratton Publisher 1984: p. 151-74.

[25] Bandyopadhyay B, Nandi S, Mitra K, et al. A comparative study on perceptions and practices among parents of thalassemic children attending two different Institutions. Indian J Community Med 2007;28:1-5.

[26] Chhotray GP, Dash BP, Ranjit M. Spectrum of haemoglobinopathies in Orissa, India. haemoglobin 2004;28(2):117-22.

[27] Shah N, Mishra A, Chauhan D, et al. Study on effectiveness of transfusion program in thalassemia major patients receiving multiple blood transfusions at a transfusion centre in Western India. Asian J Transfus Sci 2010;4(2):94-8.

[28] Ibrahim HM, Azab AA, Kamal NM, et al. Early detection of myocardial dysfunction in poorly treated pediatric thalassemia children and adolescents: two Saudi centers experience. Ann Meg Surg (Lond) 2016;9:6-11.

[29] Hossain MS, Raheem E, Sultana TA, et al. Thalassemias in South Asia: clinical lessons learnt from Bangladesh. Orphanet J Rare Dis 2017;12(1):93.

[30] Zamani R, Khazaei S, Rezaeian S. Survival analysis and its associated factors of beta thalassemia major in Hamadan Province. Iran J Med Sci 2015;40(3):233-9.

[31] Bejaoui M, Guirat N. Beta thalassemia major in a developing country: epidemiological, clinical and evolutionary aspects. Mediterr J haematol Infect Dis 2013;5(1):e2013002.

[32] Al-Kherbash HA, Al-Awdi A, Hasan NS. Pattern and clinical profile of thalassemia among pediatric patients attending the Yemeni Society Centers for Thalassemia and Genetic Blood Disorders in Yemen. Sci J Al-Azhar Med Fac Girls 2017;1(2):43-56.

[33] Asadi-Pooya AA, Doroudchi M. Thalassemia major and consanguinity in Shiraz city, Iran. Turk J Haematol 2004;21(3):127-30.

[34] Shah PS, Shah ND, Ray HSP, et al. Mutation analysis of $\beta$ thalassemia in East-Western Indian population: a recent molecular approach. Appl Clin Genet 2017;10:27-35.

[35] Ansari MI, Patel NG. Characterization of $\beta$-thalassemia mutations from north Maharashtra region. J Pharm Biol Sci 2015;10(3):13-6. 
[36] Patel AP, Naik MR, Shah NM, et al. Prevalence of common haemoglobinopathies in Gujarat: an analysis of a large population screening program. Natl J Comm Med 2012;3(1):112-6.

[37] Cao A, Galanello R. Beta-thalassemia. Genet Med 2010;12(2):61-76.

[38] Satpute SB, Bankar MP, Momin AA. The prevalence of $\beta$ thalassemia mutations in south western Maharashtra. Ind J Clin Biochem 2012;27(4):389-93.

[39] Panja A, Ghosh TK, Basu A. Genetics of thalassemia in Indian population. $\mathrm{J}$ Community Nutr Health 2012;1(1):39-46.

[40] Bhukhanvala DS, Italia K, Sawant P, et al. Molecular characterization of $\beta$-thalassemia in four communities in South Gujarat-codon $30(\mathrm{G} \rightarrow \mathrm{A})$ a predominant mutation in the Kachhiya Patel community. Ann haematol 2013;92(11):1473-6.

[41] Colah RB, Gorakshakar AC, Nadkarni AH. Invasive \& noninvasive approaches for prenatal diagnosis of haemoglobinopathies: experiences from India. Ind J Med Res 2011;134(4):552-60.

[42] Hassan S, Ahmad R, Zakaria Z, et al. Detection of $\beta$-globin gene mutations among $\beta$-thalassaemia carriers and patients in Malaysia: application of multiplex amplification refractory mutation system-polymerase chain reaction. Malays J Med Sci 2013;20(1):13-20.

[43] Thong MK, Tan JA, Tan KL, et al. Characterisation of betaglobin gene mutation in Malaysian children: a strategy for the control of beta-thalassemia in a develop country. J Trop Pediatr 2005;51(6):328-33.

[44] Colah R, Gorakshakar A, Nadkarni A, et al. Regional heterogeneity of beta-thalassemia mutations in the multi ethnic Indian population. Blood Cells Mol Dis 2009;42(3):241-6.

[45] Nadkarni AH, Nair SB, Italia KY, et al. Molecular diversity of haemoglobin $\mathrm{H}$ disease in India. Am J Clin Pathol 2010;133(3):491-4.

[46] Dehury S, Purohit P, Meher S, et al. Compound heterozygous state of $\beta$-thalassemia with IVS1-5 $(\mathrm{G} \rightarrow \mathrm{C})$ mutation and Indian deletion-inversion $\mathrm{G} \gamma(\mathrm{A} \gamma \delta \beta)(0)$ thalassemia in eastern India. Rev Bras haematol haemoter 2015;37(3):202-6.

[47] Murali DB, Leena B, Gorinabele RS, et al. Molecular genetic analyses of $\beta$-thalassemia in South India reveals rare mutations in the beta-globin gene. J Hum Genet 2004;49(8):408-13.

[48] Kirti G, Minakshi V, Pankaj A, et al. Beta thalassemia in India: current status and the challenges ahead. International Journal of Pharmacy and Pharmaceutical Sciences 2014;6(4):28-33.

[49] Sinha S, Black ML, Agarwal S, et al. Profiling $\beta$ thalassaemia mutations in India at state and regional levels: implications for genetic education, screening and counselling programmes. Hugo J 2009;3(1-4):51-62.

[50] Galanello R, Melis MA, Ruggeri R, et al. Beta 0 thalassemia trait in Sardinia. haemoglobin 1979;3(1):33-46.

[51] Nagel RL, Steinberg MH. haemoglobin SC disease and HbC disorders. In: Steinberg MH, Forget BG, Higgs DR, et al. eds. Disorders of haemoglobin: genetics, pathophysiology, and clinical management. New York: Cambridge University Press 2001: p. 756-85.

[52] Steinberg MH. Compound heterozygous and other sickle haemoglobinopathies. In: Steinberg MH, Forget BG, Higgs $\mathrm{DR}$, et al. eds. Disorders of haemoglobin: genetics, pathophysiology and clinical management. New York: Cambridge University Press 2001: p. 786-810.

[53] Bhukhanvala D, Seliya V, Shah A, et al. Study of parents of $\beta$-thalassemia major children to determine cutoff values of haematological parameters for diagnosis of $\beta$ thalassemia trait and assessment of anaemia in them. Indian J Med Sci 2013;67(5-6):117-22.

[54] Soliman AR, Kamal G, Walaa AE, et al. Blood indices to differentiate between $\beta$-thalassemia trait and iron deficiency anaemia in adult healthy Egyptian blood donors. Egypt J Haematol 2014;39(3):91-7.

[55] Parthasarathy V. Search for beta thalassemia trait in India. Turk J haematol 2012;29(4):427-9. 